\title{
Association between Chronotype and Nutritional, Clinical and Sociobehavioral Characteristics of Adults Assisted by a Public Health Care System in Brazil
}

\author{
Juliana C. Reis-Canaan ${ }^{1}$, Marcelo M. Canaan ${ }^{1}$, Patrícia D. Costa ${ }^{1}$, Tamires P. Rodrigues-Juliatte ${ }^{1}$, \\ Michel C. A. Pereira ${ }^{1}$, Paula M. Castelo ${ }^{2}$, Vanessa Pardi ${ }^{3}$, Ramiro M. Murata ${ }^{3, *}$ and Luciano J. Pereira ${ }^{1, *}$ (D) \\ 1 Health Sciences Faculty, Universidade Federal de Lavras (UFLA), Lavras 37200-900, MG, Brazil; \\ reisjuliana@yahoo.com.br (J.C.R.-C.); marcelo.canaan@ufla.br (M.M.C.); \\ patriciadaniela.costa@yahoo.com.br (P.D.C.); tamires.rodrigues@hotmail.com (T.P.R.-J.); \\ deangelis@ufla.br (M.C.A.P.) \\ 2 Department of Pharmaceutical Sciences, Universidade Federal de São Paulo (UNIFESP), \\ Diadema 09913-030, SP, Brazil; paula.castelo@unifesp.br \\ 3 Department of Foundational Sciences, School of Dental Medicine, East Carolina University (ECU), \\ Greenville, NC 27834, USA; pardiv19@ecu.edu \\ check for \\ * Correspondence: muratar16@ecu.edu (R.M.M.); lucianojosepereira@ufla.br (L.J.P.); \\ Tel.: +1-252-737-6960 (R.M.M.); +55-35-3829-5211 (L.J.P.)
} updates

Citation: Reis-Canaan, J.C.; Canaan, M.M.; Costa, P.D.; Rodrigues-Juliatte, T.P.; Pereira, M.C.A.; Castelo, P.M.; Pardi, V.; Murata, R.M.; Pereira, L.J. Association between Chronotype and Nutritional, Clinical and Sociobehavioral Characteristics of Adults Assisted by a Public Health Care System in Brazil. Nutrients 2021, 13, 2260. https://doi.org/10.3390/ nu13072260

Academic Editors: Maria

Luz Fernandez and Megan

A. McCrory

Received: 3 May 2021

Accepted: 26 June 2021

Published: 30 June 2021

Publisher's Note: MDPI stays neutral with regard to jurisdictional claims in published maps and institutional affiliations.

Copyright: (c) 2021 by the authors. Licensee MDPI, Basel, Switzerland. This article is an open access article distributed under the terms and conditions of the Creative Commons Attribution (CC BY) license (https:/ / creativecommons.org/licenses/by/ $4.0 /)$.

\begin{abstract}
Chronotype (CT) has been associated with predisposition to chronic noncommunicable diseases (CNCDs), such as diabetes mellitus and obesity. However, the effects of CT on individuals assisted by public health systems (PHSs) in middle-up economies are still poorly explored. The objective of this study was to evaluate the relationship between CT and clinical, sociobehavioral and nutritional aspects in adults assisted by a PHS in Brazil. This is a population-based cross-sectional study. The sample consisted of 380 individuals, selected through probabilistic sampling by clusters, in all health units in a city of approximately 100 thousand inhabitants. Data collection was performed during home visits, by means of general and nutritional interviews, anthropometric measurements and the Morningness-Eveningness Questionnaire (MEQ). Statistical analysis comprised chi-square test and principal component analysis (CPA) followed by Fisher's discriminant analysis to determine aspects associated with each CT (morning, evening or intermediate). With the aim of explaining the variation in the CT scores, the consumption of micronutrients (corrected to the total energy intake) and other individual and sociodemographic variables were used as explanatory factors in the adjustment of a linear regression model. The morning group was characterized by older men, with less than eight years of schooling, with low body mass index (BMI) and with low intake of omega-6, omega-3, sodium, zinc, thiamine, pyridoxine and niacin. The evening group, on the other hand, was composed of younger individuals, with a high consumption of these same nutrients, with high BMI and a higher frequency of heart diseases $(p<0.05)$. It was concluded that most morning CT individuals were elderly thin males with lower consumption of omega- 6 and -3 , sodium, zinc, thiamine, pyridoxine and niacin, whereas evening individuals were younger, had higher BMI and had higher consumption of the studied micronutrients. The identification of circadian and behavioral risk groups can help to provide preventive and multidisciplinary health promotion measures.
\end{abstract}

Keywords: diet; circadian rhythm; heart disease; micronutrients

\section{Introduction}

Chronotype (CT) represents an individual's circadian phenotype (e.g., one's behavioral preference) [1-3], generating performance patterns as morning, evening or intermediate types $[4,5]$. Although CT has a genetic basis, it is also influenced by environmental, biological and social factors [1,6-8]. Epidemiological studies demonstrate a normal distribution of 
$\mathrm{CT}$ in the population $[3,9]$ and several tools may be used to determine $\mathrm{CTs}$, ranging from questionnaires to hormonal measures $[5,10,11]$.

Human beings are able to subvert the light-dark cycle, and metabolic functions together with social interactions may influence the circadian rhythm. Nutrient intake and meal distribution along the day/night periods and hormonal secretions integrate metabolism signals to the central clock $[7,12]$. The unbalance of the physiological synchrony may be associated with the appearance of chronic noncommunicable diseases (CNCDs) [1,13,14].

CNCDs such as diabetes mellitus and obesity represent important public health challenges worldwide due to the morbidity, mortality and elevated associated costs [15-19]. Studies have established a potential association between CT and the aforementioned diseases, mainly with regards to the eveningness preference [20,21]. Besides, a link between cancer and CT has also been reported [13,22-24]. The chronic misalignment between internal physiological signals and externally imposed timing of day-to-day work increase the risk of mortality for the evening CT $[13,20,25,26]$. Dietary patterns and food intake exhibit daytime rhythms, with possible influence of CT $[1,22,27,28]$. Individuals with an evening CT have unfavorable eating habits, tending to consume fewer but larger meals and to skip breakfast and delay food intake due to late awakening [29-31].

In Brazil, most people with CNCDs depend on the public health system (PHS) to receive adequate treatment, through the Family Health Strategy (FHS). Brazil is an uppermiddle-income economy [32] but still has high inequalities and significant disparities among different regions. In this context, the FHS represents the main policy to favor health accessibility to the population. It plays an important role in reducing social and health disparities in populations of socioeconomic vulnerability [33,34].

Social conditions may influence the period of exposure to light [1] due to work routines and consequently influence CT. Understanding such differences can guide the development of cost-effective collective health promotion strategies. The implication of such chronotypedriven differences in dietetic nutrition is yet to be fully elucidated in people assisted by a PHS. Thus, the present study aimed to investigate the relationship between CT, diet and $\mathrm{CNCD}$, analyzing clinical, sociobehavioral and nutritional aspects.

\section{Materials and Methods}

The present study was approved by the Human Research Ethics Committee of the Federal University of Lavras (COEP/UFLA, MG, Brazil—CAAE: 29523220.0.0000.5148). All procedures were in accordance with the Ministry of Health Resolution 466/12 from the Brazilian Government. According to the protocol, all participants were informed about the research objectives and signed the Free and Informed Consent Form (FICF). The study was carried out in the units of the Family Health Strategy (FHS) in the city of Lavras (approximately 102,000 citizens), latitude $21^{\circ} 14^{\prime} 43$ south and longitude $44^{\circ} 59^{\prime} 59$ west, in the state of Minas Gerais, Brazil. In accordance with the last survey in 2010, the Human Development Index (HDI) of Lavras corresponds to 0.782, occupying 5th place in the state of Minas Gerais.

\subsection{Study Design and Sampling}

All 17 health units of the city were included in the study, and the participants were selected proportionally and systematically among them. Participants were randomly selected by means of probabilistic sampling by clusters within people registered in the FHS at the time of the project's start (52,628 individuals). The inclusion criteria comprised individuals from both sexes and over 18 years of age. Pregnant women and people with mental illness were excluded. Individuals with drastic and recent changes in dietary patterns, such as chronic renal patients and athletes, and those under restrictive diets for weight loss/gain were also excluded in order to avoid bias.

For the sample calculation, we considered the estimated prevalence of overweight/ obesity/metabolic syndrome in Brazil ( 40\%) [35-37], 95\% confidence interval and 5\% 
accuracy, generating a minimum sample of 172 individuals. Due to the great variability in the reported prevalence, this number was increased by $100 \%$, resulting in a minimum number of 344 participants (Figure 1).

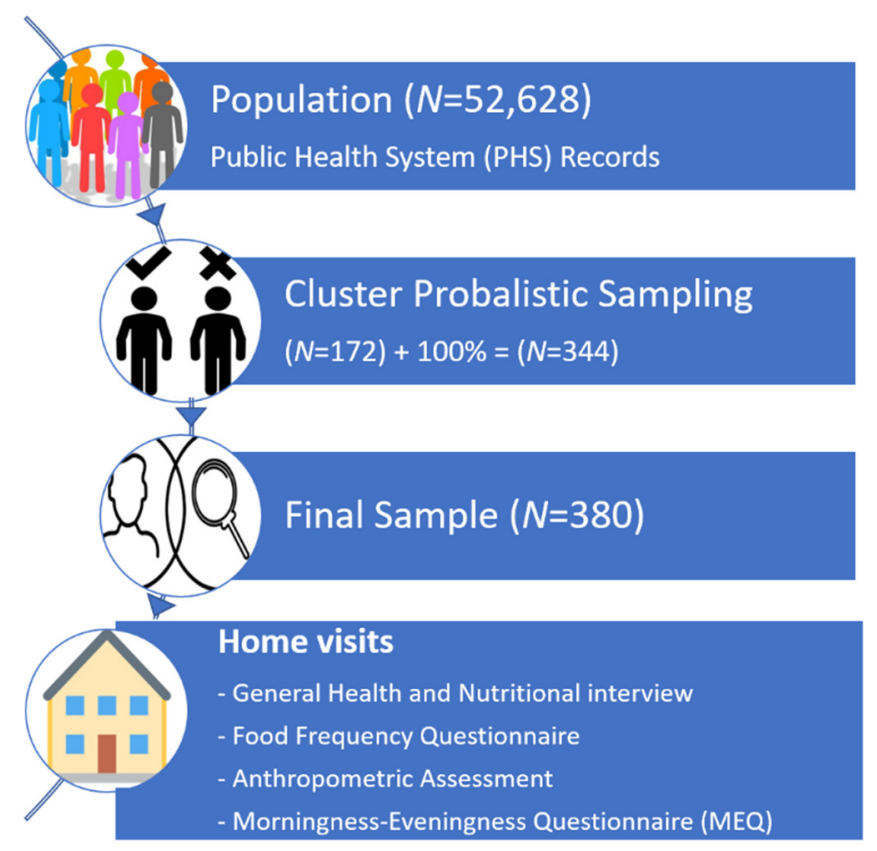

Figure 1. Fluxogram of study design. Creative Commons (CC) Licensing: "Association-communitygroup-meeting-152746" and "Search-people-selection-find-well-2831336" by OpenClipartVectors/27400 images and PaliGraficas, respectively, via Pixabay. Licensed under free for commercial use, no attribution required. "People selection" by B. Farias, CL, via thenounproject.com is licensed under CC 0. "House Emoji Icon" by "Twitter Emoji Follow" via iconscout.com is licensed under CC 0.

Data collection was carried out through cross-sectional home visits, assessing nutritional aspects and clinical and sociodemographic characteristics in order to verify the existence of an association between them and the sample's CT. On the day of the visit, the Food Frequency Questionnaire (FFQ) [38] was applied and followed by a general anamnesis, anthropometric measurements and CT profile assessment (further description). The information on food was collected with aid of a photo album, and the FFQ was adapted to portion sizes [39]. All procedures were performed by a previously trained nutritionist, except the evaluation of the $\mathrm{CT}$, which was applied by another health professional from the team.

The dietary record was evaluated for the intake of the following nutrients as described previously [40]: omega-3, omega-6, fiber, calcium (Ca), magnesium ( $\mathrm{Mg})$, manganese ( $\mathrm{Mn})$, phosphorus $(\mathrm{P})$, iron $(\mathrm{Fe})$, sodium $(\mathrm{Na})$, potassium $(\mathrm{K})$, copper $(\mathrm{Cu})$, zinc $(\mathrm{Zn})$, vitamin $\mathrm{A}$ (retinol), thiamine, riboflavin, pyridoxine, niacin and vitamin C. In addition to these, the intake of macronutrients such as carbohydrates, proteins and lipids was quantified and associated with the respective energy content. For the estimation of dietary consumption of nutrients, we used a conversion table (TACO table) [41].

Anthropometric measurements were performed according to the Technical Standard of the Food and Nutrition Surveillance System (SISVAN) [42]. We evaluated body weight, height and waist circumference. The body mass index (BMI) was calculated using the formula BMI $=($ weight $(\mathrm{kg})) /(\text { height }(\mathrm{m}))^{2}$ [43]. Waist circumference was measured and classified to assess the risk of metabolic complications.

We also used the Morningness-Eveningness Questionnaire (MEQ) by Horne and Östberg [5], translated and adapted to Portuguese language [44] to determine each participant's CT. The interview consists of 19 questions with objective answers previously defined and is self-assessed. For each answer, a specific score is generated, and the total 
sum of the answers varies from 16 to 86 points. Scores less than 41 points are compatible with "evening types", between 42 and 58 points are "intermediate types" and higher than 59 points indicate "morning types".

At the same time, individuals were asked about general life habits, history of diseases, long-term treatment medications and socioeconomic status. The sociodemographic and clinical characteristics evaluated were age, sex, educational level, income, physical activity frequency, smoking, consumption of alcoholic beverages and the presence of CNCDs (diabetes mellitus, hypertension, hypercholesterolemia, hypertriglyceridemia, hypothyroidism, liver steatosis, cardiopathy, cancer history, depression). Some of these variables were dichotomized, namely educational level $\geq 8$ years of study, smoking yes or no and family income up to two minimum wages or higher (approximately USD 500) [40] (Figure 1).

\subsection{Statistical Analysis}

Statistical analysis was performed using SPSS 26.0 software considering an alpha level of $5 \%$ by an applied statistics spec (PMC). Descriptive statistics consisted of means, standard deviations and percentages. Missing random data occurred in only 9 observations (monotone missing pattern), and data imputation was performed predicting the missing data by linear regression. Chi-square test was applied to compare the frequencies of categorical variables among the three chronotypes (morning, evening or intermediate).

In order to summarize the number of nutritional variables, principal component analysis was used to estimate the number of components emerging from the intake of the following micronutrients: omega- 6 , omega-3, fiber, calcium, magnesium, manganese, phosphorus, iron, sodium, potassium, copper, zinc, retinol, thiamine, riboflavin, pyridoxine, niacin and vitamin C [40]. First, the correlation matrix of the standardized variables was examined, and the number of components to retain was based on eigenvalues, total of explained variance and scree plot examination. As the variables showed moderate correlations, the oblimin rotation was performed. The overall Kaiser-Meyer-Olkin (KMO) measure and Bartlett's test of sphericity were examined as assumptions of the test [40].

Further, Fisher's discriminant analysis was used to ascertain which of the clinical, sociobehavioral and nutritional aspects (protein, lipid and carbohydrate intake and micronutrient component loadings generated from principal component analysis) would be significant to discriminate the CT groups of participants. The following assumptions of the test were observed: independence of observations, multivariate normality and homogeneity of variance (Box's M statistic).

With the aim of explaining the variation in the CT scores, the consumption of micronutrients (corrected to the total energy intake) and other individual and sociodemographic variables were used as explanatory factors in the adjustment of a linear regression model. The following micronutrients were included in the analysis: zinc, retinol, omega-6, omega-3, thiamine, copper, niacin, manganese, sodium, cholesterol, vitamin C, pyridoxine, riboflavin, fiber, calcium, tryptophan, iron, magnesium, potassium and phosphorus, in addition to the variables age, sex and BMI. The backward procedure was used to obtain the final model, after examining the changes in the adjusted R2 and F-values for each independent variable excluded from the model. The assumptions of the test, namely normality, collinearity (VIF and tolerance), independence of errors (Durbin-Watson) and homoscedasticity (residual analysis), were also considered to obtain the best fit.

\section{Results}

Table 1 shows an exploratory analysis of the sample, as well the frequencies of chronic diseases according to each CT. The percentage of females was similar between groups, while the morning CT group showed the higher mean age and the lower percentage of individuals with at least 8 years of schooling. The frequency of heart diseases was different among chronotypes, being higher in the evening CT group, although it is important to consider the small number of individuals of this group. 
Table 1. Sociodemographic and clinical characteristics of the sample according to sex.

\begin{tabular}{|c|c|c|c|c|}
\hline Chronotype & & $\begin{array}{l}\text { Morning } \\
(n=252)\end{array}$ & $\begin{array}{l}\text { Intermediate } \\
\quad(n=119)\end{array}$ & $\begin{array}{l}\text { Evening } \\
(n=13)\end{array}$ \\
\hline \multicolumn{5}{|l|}{ Clinical and sociobehavioral aspects } \\
\hline Age (years) * & mean (SD) & $53.5(0.7)$ & $46.5(1.2)$ & $42.4(2.7)$ \\
\hline BMI $\left(\mathrm{Kg} / \mathrm{m}^{2}\right)$ & mean (SD) & $29.0(0.4)$ & $29.3(0.6)$ & $31.4(2.5)$ \\
\hline Sex (female) & $\%$ & 77 & 83 & 85 \\
\hline Schooling * (>8 years) & $\%$ & 49 & 66 & 62 \\
\hline Income ( $>2$ min wage) & $\%$ & 36 & 36 & 9 \\
\hline Physical activity (>3x a week) & $\%$ & 36.5 & 24 & 38.5 \\
\hline Smoking habit (yes) & $\%$ & 21 & 21 & 31 \\
\hline Alcohol consumption ( $\geq 2$ times/week) & $\%$ & 10 & 12 & 15 \\
\hline \multicolumn{5}{|l|}{ Chronic diseases } \\
\hline Diabetes mellitus (yes) & $\%$ & 32 & 24 & 31 \\
\hline Hypertension (yes) & $\%$ & 54 & 52 & 31 \\
\hline Hypercholesterolemia (yes) & $\%$ & 26 & 22 & 7 \\
\hline Hypertriglyceridemia (yes) & $\%$ & 2 & 2.5 & 0 \\
\hline Hypothyroidism (yes) & $\%$ & 5 & 9 & 0 \\
\hline Liver steatosis (yes) & $\%$ & 1 & 2.5 & 8 \\
\hline Heart diseases (yes) * & $\%$ & 7.5 & 1 & 15 \\
\hline Kidney disease (yes) & $\%$ & 0.5 & 1 & 0 \\
\hline Circulatory system disease (yes) & $\%$ & 0.5 & 0 & 0 \\
\hline Depression (yes) & $\%$ & 6 & 2.5 & 15 \\
\hline \multicolumn{5}{|l|}{ Nutritional aspects } \\
\hline Total energy intake (Kcal) & mean (SD) & $1522.3(27.8)$ & $1633.6(42.4)$ & $1649.0(91.5)$ \\
\hline Protein intake $(\mathrm{g})$ & mean (SD) & $62.3(1.3)$ & $66.8(1.9)$ & $63.9(3.9)$ \\
\hline Lipid intake (g) & mean (SD) & $42.0(1.0)$ & $46.1(1.4)$ & $42.1(3.6)$ \\
\hline Carbohydrate intake (g) & mean (SD) & $222.9(4.1)$ & $235.4(6.7)$ & $248.2(16.3)$ \\
\hline
\end{tabular}

${ }^{*} p<0.05$ (chi-squared test).

A principal component analysis (PCA) with oblimin rotation was used to identify micronutrient dietary patterns within the study population; an overall Kaiser-Meyer-Olkin (KMO) measure equal to 0.82 was found, and the Bartlett's test of sphericity was statistically significant $(p<0.0001)$, indicating that the data were likely factorizable. After oblimin rotation of the components, PCA revealed that the first three components explained $75 \%$ of the total variance, as confirmed by the visual inspection of the scree plot. As such, three components met the interpretability criterion and were retained, as observed in Table 2.

For interpretation purposes, by examining Table 2 it can be assumed that for Component 1 , the higher the component, the higher the loadings of omega- 6 and -3 , sodium, zinc, thiamine, pyridoxine and niacin intake; for Component 2, the higher the component, the higher the loadings of fiber, magnesium, manganese, iron, potassium, copper and vitamin $\mathrm{C}$ intake; and for Component 3 , the higher the component, the higher the loadings of calcium, phosphorus, retinol and riboflavin intake.

Further, Fisher's discriminant analysis was performed to discriminate the three CT groups from the following variables: age, sex, BMI, physical activity, alcohol consumption and nutritional aspects. Two discriminant functions were obtained (F1 and F2), and 87\% of the variance was explained by F1 ( $p=0.001)$ (Box's M statistic: $p=0.545)$. According to F1, the standardized coefficients indicate that the variable 'age' is the most important predictor, followed by Component 1 , sex and BMI, in discriminating groups, as follows:

$\mathrm{F} 1=-0.20 \times \mathrm{BMI}+0.72 \times$ Age $-0.68 \times$ Component $1+0.12 \times$ Protein $+0.17 \times$ Lipid $+0.10 \times$ Carbohydrate + $0.16 \times$ PhysActivity $+0.25 \times$ Sex $+0.03 \times$ Alcohol

F2 $=0.42 \times$ BMI $-0.11 \times$ Age $+0.30 \times$ Component $1-0.19 \times$ Protein $-0.91 \times$ Lipid $+0.52 \times$ Carbohydrate + $0.63 \times$ PhysActivity $+0.13 \times$ Sex $+0.17 \times$ Alcohol 
Table 2. Micronutrient intake patterns obtained by principal component analysis with oblimin rotation (three components retained).

\begin{tabular}{cccc}
\hline & \multicolumn{1}{c}{ Component } & $\mathbf{3}$ \\
\hline omega-6 & 0.784 & $\mathbf{2}$ & \\
omega-3 & 0.690 & 0.356 & \\
fiber & 0.334 & 0.833 & \\
calcium & & 0.883 \\
magnesium & & 0.722 & \\
manganese & 0.319 & 0.599 & 0.632 \\
phosphorus & 0.343 & 0.656 & \\
iron & 0.580 & 0.732 & 0.361 \\
sodium & 0.720 & & 0.829 \\
potassium & & & \\
copper & 0.631 & & \\
zinc & & & \\
retinol & 0.577 & 0.718 & \\
thiamine & & & \\
riboflavin & 0.719 & & \\
pyridoxine & 0.716 & & \\
niacin & -0.389 & & \\
vitamin C & & & \\
\hline
\end{tabular}

Coefficients smaller than 0.30 are omitted.

As observed in Figure 2, F1 discriminates better between the morning CT (blue dots) and the other groups, as its mean is reasonably different from the others, while F2 helps to discriminate between evening CT (green dots) and the other two groups. Based on the findings, the morning CT classification results from a higher age, lower Component 1 (that is, omega- 6 and -3 , sodium, zinc, thiamine, pyridoxine and niacin intake), male sex and lower BMI; on the other hand, lower age, higher BMI and higher Component 1 favor the evening CT classification.

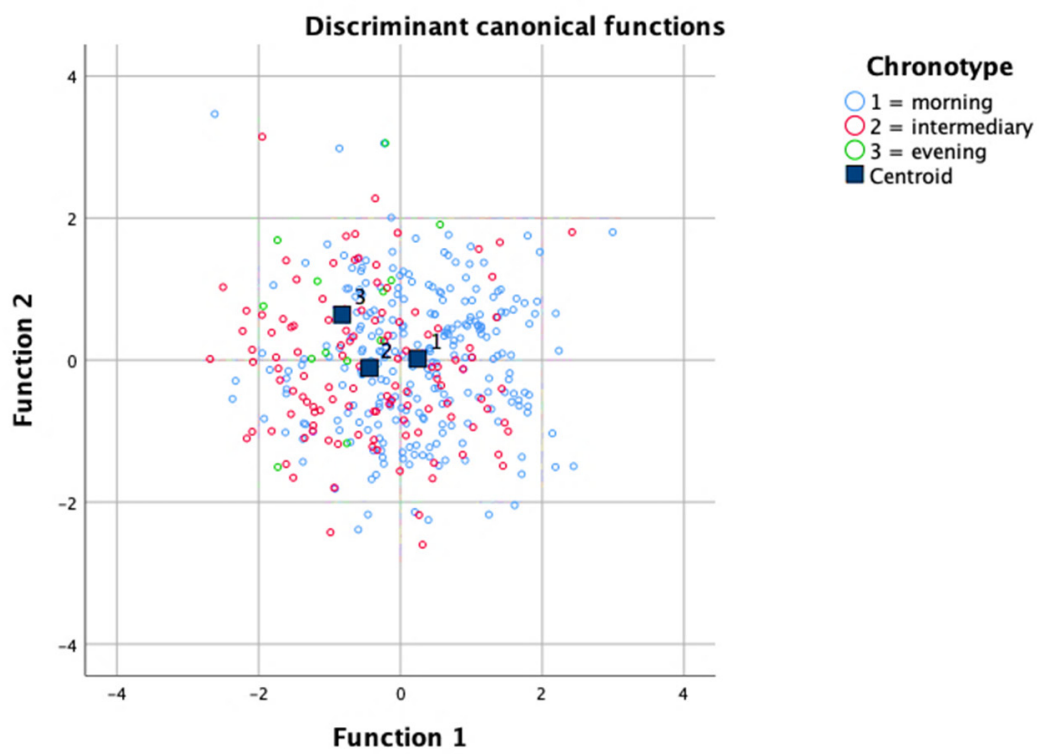

Figure 2. Graphical analysis of the discriminatory power of the two functions and centroids of the three groups. Function 1 (X axis) discriminates better between the morning chronotype (CT) (blue dots) and the other groups, as its mean is reasonably different from the others, while Function 2 ( $\mathrm{Y}$ axis) helps to discriminate between evening CT (green dots) and the other two groups. Function 1 explained $87 \%$ of the variance $(p=0.001)$ (Box's M statistic: $p=0.545)$. 
The linear regression model was adjusted with the aim of explaining the variation in CT scores (Table 3). The CT scores were predicted by age and the intake of magnesium, sodium, omega- 6 , fiber, zinc, retinol and pyridoxine (adj R2 $=14 \% ; p<0.001$ ), meaning that higher scores were related to higher age and lower intake of omega-6, fiber, zinc, retinol and pyridoxine. It is possible to observe that the results of the linear model are in agreement with the results of the functions obtained by discriminant analysis, as they share the same hypothesis and the only difference is the dependent variable: CT scores and CT groups, respectively. The regression model showed good fit, as observed by the parameters of tolerance, VIF, residual analysis and independence of errors (Durbin-Watson).

Table 3. Final predictive model for estimation of the CT scores.

\begin{tabular}{|c|c|c|c|c|c|c|c|c|}
\hline $\begin{array}{l}\text { Dependent } \\
\text { Variable }\end{array}$ & $\begin{array}{l}\text { Independent } \\
\text { Variables }\end{array}$ & B & CI $(95 \%)$ & $\mathbf{t}$ & Sig & $\mathbf{F}$ & Adj R2 & $\begin{array}{l}\text { Durbin- } \\
\text { Watson }\end{array}$ \\
\hline \multirow{9}{*}{ CT scores } & constant & 59.73 & $50.42-69.04$ & 12.62 & $<0.0001$ & \multirow{9}{*}{8.471} & \multirow{9}{*}{0.138} & \multirow{9}{*}{1.959} \\
\hline & age & 0.20 & $0.12-0.27$ & 5.01 & $<0.0001$ & & & \\
\hline & omega- 6 & -1001.14 & $-1944.95--57.33$ & -2.09 & 0.038 & & & \\
\hline & fiber & -431.96 & $-743.55--120.37$ & -2.73 & 0.007 & & & \\
\hline & magnesium & 69.85 & 25.99-113.71 & 3.13 & 0.002 & & & \\
\hline & sodium & 6.37 & $0.82-11.92$ & 2.26 & 0.025 & & & \\
\hline & zinc & -1337.11 & $-2397.76--276.47$ & -2.48 & 0.014 & & & \\
\hline & retinol & -25.93 & $-42.51--9.35$ & -3.08 & 0.002 & & & \\
\hline & pyridoxine & -8509.37 & $-14,441.69--2577.06$ & -2.82 & 0.005 & & & \\
\hline
\end{tabular}

CT: Chronotype; B: Beta coefficient; CI: confidence interval; t: t statistics; F: F statistics; Adj R2: adjusted R squared

\section{Discussion}

The findings of the present study revealed associations between CT and sociobehavioral and dietary patterns among individuals assisted by the PHS. Morning and evening individuals showed opposite characteristics regarding age, BMI and the ingestion of Component 1 nutrients. The former group included older male individuals with lower BMI and lower intake of Component 1. Morning individuals presented lower educational level. The evening CT group, on the other hand, was composed mainly of individuals with lower age, higher BMI and also higher Component 1 intake. Moreover, this group showed a greater risk of heart diseases.

In the present study, age was the most important predictor for discriminating the morning CT. Important events favoring morningness begin around the age of 50 [45]. These changes include alterations in the expression of several genes related to the circadian clock [46] and a reduction in the secretion of circulating hormones (especially melatonin and cortisol) [47], leading to decreased sleep [48,49].

Another important factor discriminating CT was sex, with most matutine participants being males. Indeed, men's and women's biological rhythms are quite different, with the latter tending to go to bed earlier, to wake up earlier and to prefer morning activities [50-53]. However, the evaluated sample comprises a group of people with social vulnerability. Most of the interviewed women used to be housewives, while men were responsible for working outside the home. This means that men wake up earlier, often even on weekends, a fact that might be related to social jetlag [6].

Most of the morning CT participants showed fewer years of education in our study. The relationship between $\mathrm{CT}$, intelligence and academic performance has been described in a controversial way in the literature $[51,54,55]$. Evening individuals are positively related to cognitive ability, yet negatively related to indicators of academic achievement [51] due to social jetlag (desynchronosis caused by misalignment between social and biological clocks) [6,55]. Panev et al. found that evening individuals present a higher level of intelligence, but these advantages disappear when social jetlag is greater than $2 \mathrm{~h} \mathrm{[55].} \mathrm{Mistimed}$ sleep is able to alter the expression of circadian genes [49,56]. However, it is important to highlight that pressures for working and sleep timing can also interfere with the CT. Then, morning CT is more common in people who work on a daily basis [57]. Our data are in 
accordance with the Brazilian Institute of Geography and Statistics (IBGE), which reported that despite the advances achieved in the latest assessments, more than $50 \%$ of the Brazilian population aged 25 or more had not completed basic and compulsory school education [58]. We were surprised by the small number of evening individuals in the present sample. In a previous study in our country, the prevalence of the evening type was $32 \%$, whereas $54 \%$ were intermediate, and $14 \%$ were morning type. This previous study investigated 648 individuals between 17 and 49 years of age [59]. However, our sample comprised older individuals and individuals living mostly under socioeconomic vulnerability. The average MEQ score increases linearly with age [60], leading to intermediate and morning types. In other words, the higher the age, the higher the score, which is compatible with intermediate or morning CT. Another reason for the large number of morning chronotypes in our study could be that due to unfavorable socioeconomic conditions, many individuals were pressured to wake up very early and work double or night shifts as a strategy to maintain employment and improve family income. This result highlights the importance of raising education and qualification of young people as a way to combat the significant inequality in the country [58].

We also found that evening individuals were more prone to heart diseases. Circadian clocks are present in different cells of the cardiovascular system [61,62]. Several cardiovascular functions such as blood pressure control, heart rate, endothelial function and thrombus formation can be influenced by circadian rhythm $[62,63]$. There is evidence that Clock genes are involved in the homeostatic function of the endothelium, since these genes control both thrombomodulin and the plasminogen activator inhibitor-1 (PAI-1) in endothelial cells, essential in balancing coagulation and fibrinolysis processes $[64,65]$. Based on the aforementioned knowledge, significant circadian misalignment is recognized as a risk factor for the development of cardiovascular diseases [13]. Emerging epidemiological evidence links evening CT with cardiovascular disease [66,67]. These individuals are more predisposed to circadian misalignment due to an asynchrony (social jetlag) between their endogenous biological clocks and the time of social activities, such as food intake, work and sleep-wake cycle, making them vulnerable to cardiometabolic dysfunction [13].

Another important finding was the relationship between evening CT and high BMI. Nocturnal preference and greater social jetlag are associated with increased occurrence of overweight/obesity [56,68] and metabolic syndrome [56]. This suggests a broader involvement of the circadian clock in the pathophysiology of CNCDs [69]. Over the years, especially in the last century in modern industrialized society, there have been significant changes in zeitgebers, culminating in shorter sleep durations and higher availability of food [70]. There is more time available to eat, and people generally feel more tired and stressed, hindering their ability to follow exercise or dietary regimens [70]. Moreover, food availability became more abundant, the intake of high-calorie foods and simple sugars has increased, the frequency of snacks has increased and the timing of snacks has changed to later in the day $[70,71]$.

The central biological clock evolved to synchronize activity, feeding and sleep to diurnal and seasonal changes using hormones and the autonomic nervous system [72]. It is postulated that the thrifty genotype has evolved over millions of years to be expressed during seasons with high availability of food, periods in which there would be an increase in insulin secretion to prioritize the increase in fat deposition to prepare adaptively for the following seasons and the possibility of food scarcity [73]. Thus, in a modern Western environment with constant and easy access to food, as well as the social jetlag induced by dramatic changes in zeitgebers, the thrifty genotype would be permanently activated, leading to obesity and its respective pathological biochemical characteristics [73]. The eating behavior of evening individuals is more frequent and irregular, a fact that directly impacts the weight gain and fat mass verified in this group [71]. In this sense, chrononutritional interventions can represent cost-effective strategies with a direct impact on weight control [74]. 
With regard to energy intake, we found no differences among the three CTs. Mazri and colleagues conducted a scoping review and found that most studies did not show a significant association between CT and total daily energy intake. However, associations between evening CT and higher carbohydrate or fat consumption were reported $[1,4]$. Interestingly, a higher intake of carbohydrates/energy after 8:00 p.m. prevailed for evening individuals [4]. Mirkka et al. found that the evening types had a lower intake of macronutrients and energy in the morning when compared to the morning types. However, they presented a higher night intake of sucrose, fat and fatty acids, with no difference in the total daily energy intake [71].

In our sample, evening CT was associated with a higher consumption of Component 1 nutrients, which included omega-3 and omega-6 (a subgroup of fats) and some micronutrients. There are limited publications regarding the effects of PUFAs on circadian parameters [75]. Greco et al. found that the use of DHA attenuates the deleterious effects of palmitate (saturated fat) on the circadian profile expression of Bmal1, suggesting a protective effect of DHA [75]. On the other hand, a reduction in the consumption of saturated fats has been observed in Western countries, a fact confirmed in recent Brazilian research [76,77], as has an increase in the intake of omega-6 [76]. Increased consumption of omega- 6 can cause negative consequences for metabolic health due to its recognized proinflammatory, prothrombotic and proadipogenic effects [78]. Such a fact could contribute to the increase in the incidence of obesity and heart disease in the evening CT [79]. Evidence suggests that peripheral clocks located in adipocytes may be involved in the inflammatory state that permeates this tissue [80]. In obesogenic conditions, immune cells are recruited into adipose stores that can further amplify the inflammatory response [81]. In males exposed to circadian misalignment, the increase in inflammation and the reduction in insulin sensitivity were doubled when compared to controls who maintained regular night hours. In addition, in misaligned individuals with similar sleep conditions to those in alignment, there was a significant increase in the levels of ultrasensitive C-reactive protein, a sign of systemic inflammation and a predictor of cardiovascular disease [82].

Regarding the association between CT and micronutrients, there are few publications. In situations of deficiency in group B vitamins, there is evidence of a modest influence of supplementation on the regulation of sleep-wake rhythm modulating neurotransmission through participation in the synthesis of serotonin and melatonin [83]. It is clear that pyridoxine (B6) is involved in the synthesis of serotonin from tryptophan and that niacin (B3) can cause a sparing effect of tryptophan, benefiting the synthesis of serotonin and melatonin. Cyanocobalamin (B12) also contributes to the secretion of melatonin. However, melatonin secretion is influenced by light exposure, and its relationship with sleep quality and CT is not linear [83]. We also found a high intake of some group B vitamins, such as thiamine (B1), pyridoxine and niacin, in Component 1, which was observed in the evening CT. However, it is not possible to state that the high intake of these vitamins seen in Component 1 is directly related to supraphysiological levels, as they are water-soluble vitamins (without storage). No association was found between cyanocobalamin intake and CT in our analysis. Regarding the consumption of thiamine, Shibata et al. found similar results in a study with young Japanese women [84]. In a murine experiment with animals deficient in thiamine, after the normalization of consumption, animals' daily rhythm of regulating body temperature was restored [85]. However, it is not possible to affirm that the greater consumption of thiamine in the evening CT (lower consumption in the morning $\mathrm{CT}$ ) reflects necessarily excessive/deficient organic levels or even that this has specific repercussions for these individuals.

Many aspects remain uncertain with appreciating micronutrients in regard to the association between mineral intake and CT [4]. Comparative sources in the literature are very scarce, and we found few previous studies that verified these particularities. We believe that the association between the evening CT and increased sodium consumption may be related to an exaggerated consumption of salt. Imaki et al. assessed the eating patterns of individuals with shorter sleep periods and of individuals with preserved sleep 
and found that those who do not get enough sleep tend to adopt less healthy eating habits, such as a preference for very salty foods [86]. A significant increase in daily zinc intake was also associated with evening CT in our study. This fact may be related to preferences for certain foods, such as beans, which have a guaranteed place in the daily diet of the Brazilian population. However, neutral [87] and opposite $[88,89]$ results have also been previously reported. We believe that the increased consumption of certain micronutrients and ions is a reflection of a quantitative imbalance in the evening individuals, especially in larger meals after 8:00 p.m., since they usually stay up late and eat more meals in irregular schedules and quantities [71] when compared to morning individuals.

Finally, this study was carried in a population assisted by a PHS, configured as the main primary care initiative in Brazil. Although this program has a national coverage of about 70\% [90], Brazil is still experiencing a significant increase in the incidence of CNCDs. CNCDs mainly affect people with low income and low education, either due to risk factor exposure or to low access to health information and services [91]. The nutritionist is not part of the FHS basic team. However, they take part in the Family Health Support Nucleus (FHSN), which is an itinerant additional team that assists the basic units (which is not present in all cities). As part of the multidisciplinary team, these professionals may help to establish a link between the population's nutritional needs and the health service.

Recently, chrononutrition is becoming a prominent field of research encompassing three dimensions of eating behavior: time, frequency and regularity [1]. Considering that the time and nutrient composition of the diet can modulate the biological clock, the identification of CT may represent an interesting tool in the future to manipulate aspects of the diet in public services in order to achieve better clinical responses $[92,93]$.

\section{Conclusions}

In this study, most morning $\mathrm{CT}$ individuals were elderly thin males with lower consumption of omega- 6 and -3 , sodium, zinc, thiamine, pyridoxine and niacin, whereas evening individuals were younger, had higher BMI and had higher consumption of the studied micronutrients. The identification of circadian and behavioral risk groups can help to provide preventive and multidisciplinary health promotion measures.

Author Contributions: Conceptualization, L.J.P. and R.M.M.; methodology, L.J.P. and M.C.A.P.; formal analysis, P.M.C.; investigation, J.C.R.-C., M.M.C., P.D.C. and T.P.R.-J.; resources, L.J.P. and R.M.M.; data curation, P.M.C.; writing-original draft preparation, J.C.R.-C., M.M.C. and V.P.; writing—review and editing, L.J.P., V.P., M.C.A.P. Pereira and R.M.M.; visualization, L.J.P.; supervision, L.J.P., M.C.A.P. Pereira and R.M.M.; project administration, L.J.P.; funding acquisition, L.J.P. and R.M.M. All authors have read and agreed to the published version of the manuscript.

Funding: This study was supported by the National Council for Scientific and Technological Development (Conselho Nacional de Desenvolvimento Científico and Tecnológico-CNPq), the Research and Support Foundation of the State of Minas Gerais (Fundação de Amparo and Pesquisa do Estado de Minas Gerais-FAPEMIG) and the Coordination for the Improvement of Higher Education Personnel (Coordenação de Aperfeiçoamento de Nível Superior-CAPES).

Institutional Review Board Statement: The study was conducted according to the guidelines of the Declaration of Helsinki, and the research protocol was approved by the Human Research Ethics Committee of the Federal University of Lavras (COEP/UFLA, MG, Brazil-CAAE: 29523220.0.0000.5148).

Informed Consent Statement: Written informed consent has been obtained from the patients to publish this paper.

Data Availability Statement: Data will be available upon request.

Acknowledgments: The authors acknowledge the city of Lavras, MG, Brazil and the Family Health Strategy professionals.

Conflicts of Interest: The authors declare no conflict of interest. 


\section{References}

1. Almoosawi, S.; Vingeliene, S.; Gachon, F.; Voortman, T.; Palla, L.; Johnston, J.D.; Van Dam, R.M.; Darimont, C.; Karagounis, L.G. Chronotype: Implications for Epidemiologic Studies on Chrono-Nutrition and Cardiometabolic Health. Adv. Nutr. 2019, 10, 30-42. [CrossRef] [PubMed]

2. Vitale, J.A.; Roveda, E.; Montaruli, A.; Galasso, L.; Weydahl, A.; Caumo, A.; Carandente, F. Chronotype influences activity circadian rhythm and sleep: Differences in sleep quality between weekdays and weekend. Chronobiol. Int. 2015, 32, 405-415. [CrossRef] [PubMed]

3. Allebrandt, K.V.; Roenneberg, T. The search for circadian clock components in humans: New perspectives for association studies. Braz. J. Med. Biol. Res. 2008, 41, 716-721. [CrossRef] [PubMed]

4. Mazri, F.H.; Manaf, Z.A.; Shahar, S.; Mat Ludin, A.F. The Association between Chronotype and Dietary Pattern among Adults: A Scoping Review. Int. J. Environ. Res. Public Health 2019, 17, 68. [CrossRef]

5. Horne, J.A.; Östberg, O. A Self Assessment Questionnaire to Determine Morningness Eveningness in Human Circadian Rhythms. Int. J. Chronobiol. 1976, 4, 97-110. [CrossRef] [PubMed]

6. Wittmann, M.; Dinich, J.; Merrow, M.; Roenneberg, T. Social jetlag: Misalignment of biological and social time. Chronobiol. Int. 2006, 23, 497-509. [CrossRef]

7. Foster, R.G.; Roenneberg, T. Review Human Responses to the Geophysical Daily, Annual and Lunar Cycles. Curr. Biol. 2008, 18, 784-794. [CrossRef]

8. Leonhard, C.; Randler, C. In sync with the family: Children and partners influence the sleep-wake circadian rhythm and social habits of women. Chronobiol. Int. 2009, 26, 510-525. [CrossRef]

9. Dimitrov, A.; Veer, I.M.; Kleeblatt, J.; Seyfarth, F.; Roenneberg, T.; Ising, M.; Uhr, M.; Keck, M.E.; Kramer, A.; Berger, M.; et al. Chronotype is associated with psychological well-being depending on the composition of the study sample. J. Health Psychol. 2020, 25, 1236-1247. [CrossRef]

10. Kantermann, T.; Sung, H.; Burgess, H.J. Comparing the Morningness-Eveningness Questionnaire and Munich ChronoType Questionnaire to the dim light melatonin onset. J. Biol. Rhythm. 2015, 30, 449-453. [CrossRef]

11. Levandovski, R.; Sasso, E.; Hidalgo, M.P. Chronotype: A review of the advances, limits and applicability of the main instruments used in the literature to assess human phenotype. Trends Psychiatry Psychother. 2013, 35, 3-11. [CrossRef] [PubMed]

12. Sridhar, G.R.; Sanjana, N.S.N. Sleep, circadian dysrhythmia, obesity and diabetes. World J. Diabetes 2016, 7, 515. [CrossRef]

13. Glazer Baron, K.; Reid, K.J. Circadian Misalignment and Health. Int. Rev. Psychiatry 2014, 26, 139-154. [CrossRef]

14. Prasai, M.J.; Pernicova, I.; Grant, P.J.; Scott, E.M. An endocrinologist's guide to the clock. J. Clin. Endocrinol. Metab. 2011, 96, 913-922. [CrossRef]

15. Forouzanfar, M.H.; Alexander, L.; Bachman, V.F.; Biryukov, S.; Brauer, M.; Casey, D.; Coates, M.M.; Delwiche, K.; Estep, K.; Frostad, J.J.; et al. Global, regional, and national comparative risk assessment of 79 behavioural, environmental and occupational, and metabolic risks or clusters of risks in 188 countries, 1990-2013: A systematic analysis for the Global Burden of Disease Study 2013. Lancet 2015, 386, 2287-2323. [CrossRef]

16. Sacco, R.L.; Roth, G.A.; Reddy, K.S.; Arnett, D.K.; Bonita, R.; Gaziano, T.A.; Heidenreich, P.A.; Huffman, M.D.; Mayosi, B.M.; Mendis, S.; et al. The Heart of 25 by 25: Achieving the Goal of Reducing Global and Regional Premature Deaths from Cardiovascular Diseases and Stroke: A Modeling Study From the American Heart Association and World Heart Federation. Glob. Heart 2016, 11, 251. [CrossRef]

17. Swinburn, B.A.; Sacks, G.; Hall, K.D.; McPherson, K.; Finegood, D.T.; Moodie, M.L.; Gortmaker, S.L. The global obesity pandemic: Shaped by global drivers and local environments. Lancet 2011, 378, 804-814. [CrossRef]

18. DeFronzo, R.A.; Ferrannini, E.; Groop, L.; Henry, R.R.; Herman, W.H.; Holst, J.J.; Hu, F.B.; Kahn, C.R.; Raz, I.; Shulman, G.I.; et al. Type 2 diabetes mellitus. Nat. Rev. Dis. Prim. 2015, 1, 1-22. [CrossRef]

19. Ng, M.; Fleming, T.; Robinson, M.; Thomson, B.; Graetz, N.; Margono, C.; Mullany, E.C.; Biryukov, S.; Abbafati, C.; Abera, S.F.; et al. Global, regional, and national prevalence of overweight and obesity in children and adults during 1980-2013: A systematic analysis for the Global Burden of Disease Study 2013. Lancet 2014, 384, 766-781. [CrossRef]

20. Knutson, K.L.; von Schantz, M. Associations between chronotype, morbidity and mortality in the UK Biobank cohort. Chronobiol. Int. 2018, 35, 1-9. [CrossRef] [PubMed]

21. Patterson, F.; Malone, S.K.; Grandner, M.A.; Lozano, A.; Perkett, M.; Hanlon, A. Interactive effects of sleep duration and morning/evening preference on cardiovascular risk factors. Eur. J. Public Health 2018, 28, 155-161. [CrossRef] [PubMed]

22. Buijs, F.N.; León-Mercado, L.; Guzmán-Ruiz, M.; Guerrero-Vargas, N.N.; Romo-Nava, F.; Buijs, R.M. The circadian system: A regulatory feedback network of periphery and brain. Physiology 2016, 31, 170-181. [CrossRef]

23. Hahm, B.-J.; Jo, B.; Dhabhar, F.S.; Palesh, O.; Aldridge-Gerry, A.; Bajestan, S.N.; Neri, E.; Nouriani, B.; Spiegel, D.; Zeitzer, J.M. Bedtime misalignment and progression of breast cancer. Chronobiol. Int. 2014, 31, 214-221. [CrossRef] [PubMed]

24. Schernhammer, E.S.; Laden, F.; Speizer, F.E.; Willett, W.C.; Hunter, D.J.; Kawachi, I.; Colditz, G.A. Rotating Night Shifts and Risk of Breast Cancer in Women Participating in the Nurses' Health Study. J. Natl. Cancer Inst. 2001, 93, 1563-1568. [CrossRef] [PubMed]

25. Wong, P.M.; Hasler, B.P.; Kamarck, T.W.; Muldoon, M.F.; Manuck, S.B. Social Jetlag, Chronotype, and Cardiometabolic Risk. J. Clin. Endocrinol. Metab. 2015, 100, 4612-4620. [CrossRef] 
26. Boege, H.L.; Bhatti, M.Z.; St-Onge, M.-P. Circadian rhythms and meal timing: Impact on energy balance and body weight. Curr. Opin. Biotechnol. 2021, 70, 1-6. [CrossRef]

27. Challet, E. The circadian regulation of food intake. Nat. Rev. Endocrinol. 2019, 15, 393-405. [CrossRef]

28. Armstrong, S. A chronometric approach to the study of feeding behavior. Neurosci. Biobehav. Rev. 1980, 4, 27-53. [CrossRef]

29. Reutrakul, S.; Hood, M.M.; Crowley, S.J.; Morgan, M.K.; Teodori, M.; Knutson, K.L. The relationship between breakfast skipping, chronotype, and glycemic control in type 2 diabetes. Chronobiol. Int. 2014, 31, 64-71. [CrossRef]

30. Meule, A.; Roeser, K.; Randler, C.; Kübler, A. Skipping breakfast: Morningness-eveningness preference is differentially related to state and trait food cravings. Eat. Weight Disord. 2012, 17, 304-308. [CrossRef]

31. Dashti, H.S.; Scheer, F.A.J.L.; Jacques, P.F.; Lamon-Fava, S.; Ordovás, J.M. Short Sleep Duration and Dietary Intake: Epidemiologic Evidence, Mechanisms, and Health Implications. Adv. Nutr. 2015, 6, 648-659. [CrossRef]

32. World Bank. World Bank Country and Lending Groups-World Bank Data Help Desk. Available online: https://datahelpdesk. worldbank.org/knowledgebase/articles/906519-world-bank-country-and-lending-groups (accessed on 24 March 2021).

33. Tangcharoensathien, V.; Mills, A.; Palu, T. Accelerating health equity: The key role of universal health coverage in the Sustainable Development Goals. BMC Med. 2015, 13, 101. [CrossRef] [PubMed]

34. Bastos, M.L.; Menzies, D.; Hone, T.; Dehghani, K.; Trajman, A. The impact of the Brazilian family health on selected primary care sensitive conditions: A systematic review. PLOS ONE 2017, 12, e0182336. [CrossRef]

35. Gouveia, É.R.; Gouveia, B.R.; Marques, A.; Peralta, M.; França, C.; Lima, A.; Campos, A.; Jurema, J.; Kliegel, M.; Ihle, A. Predictors of metabolic syndrome in adults and older adults from amazonas, brazil. Int. J. Environ. Res. Public Health 2021, $18,1303$. [CrossRef]

36. Abrantes, M.M.; Lamounier, J.A.; Colosimo, E.A. Overweight and obesity prevalence in Northeast and Southeast Regions of Brazil. Rev. Assoc. Med. Bras. 2003, 49, 162-166. [CrossRef]

37. Soares, D.A.; Barreto, S.M. Sobrepeso e obesidade abdominal em adultos quilombolas, Bahia, Brasil TT-El sobrepeso y la obesidad abdominal en adultos quilombolas, Bahía, Brasil TT-Overweight and abdominal obesity in adults in a quilombo community in Bahia State, Brazil. Cad. Saude Publica 2014, 30, 341-354. [CrossRef]

38. Fisberg, R.M.; Colucci, A.C.A.; Morimoto, J.M.; Marchioni, D.M.L. Food frequency questionnaire for adults from a populationbased study. Rev. Saude Publica 2008, 42, 542-545. [CrossRef]

39. Crispim, S.P.; Fisberg, R.M.; Almeida, C.C.B.; Nicolas, G.; Knaze, V.; Pereira, R.A.; Marchiori, D.M.L.; dos Santos, N.A.; Steluti, J.; Slimani, N. Manual Fotográfico de Quantificação Alimentar; Universidade Federal do Paraná: Curitiba, Brazil, 2017; ISBN 9788568566084 .

40. Costa, P.D.; Canaan, J.C.R.; Midori Castelo, P.; Campideli Fonseca, D.; Márcia Pereira-Dourado, S.; Mendonça Murata, R.; Pardi, V.; José Pereira, L. Influence of Micronutrient Intake, Sociodemographic, and Behavioral Factors on Periodontal Status of Adults Assisted by a Public Health Care System in Brazil: A Cross-Sectional Multivariate Analysis. Nutrients 2021, 13, 973. [CrossRef] [PubMed]

41. Brazilian Food Composition Table-TACO. Available online: http://189.28.128.100/nutricao/docs/taco/tab_bras_de_comp_de_ alim_doc.pdf (accessed on 9 April 2019).

42. Brasil. Health Ministry. Guidelines for the Collection and Analysis of Anthropometric Data in Health Services-Technical Standard for Food and Nuance Systems-SISVAN. 2011. Available online: https://bvsms.saude.gov.br/bvs/publicacoes/orientacoes_ coleta_analise_dados_antropometricos.pdf (accessed on 9 April 2019).

43. World Health Organization. Obesity: Preventing and Managing the Global Epidemic. In Report of a WHO Consultation; World Health Organization, 2000; p. 894.

44. Benedito-Silva, A.A.; Menna-Barreto, L.; Marques, N.; Tenreiro, S. A self-assessment questionnaire for the determination of morningness-eveningness types in Brazil. Prog. Clin. Biol. Res. 1990, 341B, 89-98. [PubMed]

45. Carrier, J.; Monk, T.H.; Buysse, D.J.; Kupfer, D.J. Sleep and morningness-eveningness in the "middle" years of life (20-59 y). J. Sleep Res. 1997, 6, 230-237. [CrossRef] [PubMed]

46. Li, Y.; Ma, J.; Yao, K.; Su, W.; Tan, B.; Wu, X.; Huang, X.; Li, T.; Yin, Y.; Tosini, G.; et al. Circadian rhythms and obesity: Timekeeping governs lipid metabolism. J. Pineal Res. 2020, 69, 1-11. [CrossRef] [PubMed]

47. Chen, C.Y.; Logan, R.W.; Ma, T.; Lewis, D.A.; Tseng, G.C.; Sibille, E.; McClung, C.A. Effects of aging on circadian patterns of gene expression in the human prefrontal cortex. Proc. Natl. Acad. Sci. USA 2016, 113, 206-211. [CrossRef] [PubMed]

48. Hofman, M.A.; Swaab, D.F. Living by the clock: The circadian pacemaker in older people. Ageing Res. Rev. $2006,5,33-51$. [CrossRef] [PubMed]

49. Archer, S.N.; Laing, E.E.; Möller-Levet, C.S.; van der Veen, D.R.; Bucca, G.; Lazar, A.S.; Santhi, N.; Slak, A.; Kabiljo, R.; von Schantz, M.; et al. Mistimed sleep disrupts circadian regulation of the human transcriptome. Proc. Natl. Acad. Sci. USA 2014, 111, E682-E691. [CrossRef]

50. Randler, C. Gender differences in morningness-eveningness assessed by self-report questionnaires: A meta-analysis. Pers. Individ. Dif. 2007, 43, 1667-1675. [CrossRef]

51. Preckel, F.; Lipnevich, A.A.; Schneider, S.; Roberts, R.D. Chronotype, cognitive abilities, and academic achievement: A metaanalytic investigation. Learn. Individ. Differ. 2011, 21, 483-492. [CrossRef] 
52. Duffy, J.F.; Cain, S.W.; Chang, A.M.; Phillips, A.J.K.; Münch, M.Y.; Gronfier, C.; Wyatt, J.K.; Dijk, D.J.; Wright, K.P.; Czeisler, C.A. Sex difference in the near-24-h intrinsic period of the human circadian timing system. Proc. Natl. Acad. Sci. USA 2011, 108, 15602-15608. [CrossRef]

53. Adan, A.; Natale, V. Gender differences in morningness-eveningness preference. Chronobiol. Int. 2002, 19, 709-720. [CrossRef]

54. Song, J.; Stough, C. The relationship between morningness-eveningness, time-of-day, speed of information processing, and intelligence. Pers. Individ. Dif. 2000, 29, 1179-1190. [CrossRef]

55. Panev, A.S.; Tserne, T.A.; Polugrudov, A.S.; Bakutova, L.A.; Petrova, N.B.; Tatarinova, O.V.; Kolosova, O.N.; Borisenkov, M.F. Association of chronotype and social jetlag with human non-verbal intelligence. Chronobiol. Int. 2017, 34, 977-980. [CrossRef]

56. Parsons, M.J.; Moffitt, T.E.; Gregory, A.M.; Goldman-Mellor, S.; Nolan, P.M.; Poulton, R.; Caspi, A. Social jetlag, obesity and metabolic disorder: Investigation in a cohort study. Int. J. Obes. 2015, 39, 842-848. [CrossRef] [PubMed]

57. Didikoglu, A.; Maharani, A.; Payton, A.; Pendleton, N.; Canal, M.M. Longitudinal change of sleep timing: Association between chronotype and longevity in older adults. Chronobiol. Int. 2019, 36, 1285-1300. [CrossRef] [PubMed]

58. IBGE. Instituto Brasileiro de Geografia e Estatística. In Pesquisa Nacional por Amostra de Domicílios Contínua-PNAD Contínua da Educação 2018; 2019; pp. 1-12. Available online: https://www.ibge.gov.br/estatisticas/sociais/habitacao/17270-pnad-continua. html (accessed on 24 February 2021).

59. Alam, M.F.; Tomasi, E.; Lima, M.S.; Areas, R.; Menna-Barreto, L. Characterization and distribution of chronotypes in southern Brazil: Gender and season of birth differences. J. Bras. Psiquiatr. 2008, 57, 83-90. [CrossRef]

60. von Schantz, M.; Taporoski, T.P.; Horimoto, A.R.; Duarte, N.E.; Vallada, H.; Krieger, J.E.; Pedrazzoli, M.; Negrão, A.B.; Pereira, A.C. Distribution and heritability of diurnal preference (chronotype) in a rural Brazilian family-based cohort, the Baependi study. Sci Rep. 2015, 5, 9214. [CrossRef] [PubMed]

61. Reilly, D.F.; Curtis, A.M.; Cheng, Y.; Westgate, E.J.; Rudic, R.D.; Paschos, G.; Morris, J.; Ouyang, M.; Thomas, S.A.; FitzGerald, G.A. Peripheral circadian clock rhythmicity is retained in the absence of adrenergic signaling. Arterioscler. Thromb. Vasc. Biol. 2008, 28, 121-126. [CrossRef] [PubMed]

62. Takeda, N.; Maemura, K. Circadian clock and cardiovascular disease. J. Cardiol. 2011, 57, 249-256. [CrossRef] [PubMed]

63. Crnko, S.; Du Pré, B.C.; Sluijter, J.P.G.; Van Laake, L.W. Circadian rhythms and the molecular clock in cardiovascular biology and disease. Nat. Rev. Cardiol. 2019, 16, 437-447. [CrossRef] [PubMed]

64. Takeda, N.; Maemura, K.; Horie, S.; Oishi, K.; Imai, Y.; Harada, T.; Saito, T.; Shiga, T.; Amiya, E.; Manabe, I.; et al. Thrombomodulin is a clock-controlled gene in vascular endothelial cells. J. Biol. Chem. 2007, 282, 32561-32567. [CrossRef]

65. Ohkura, N.; Oishi, K.; Fukushima, N.; Kasamatsu, M.; Atsumi, G.I.; Ishida, N.; Horie, S.; Matsuda, J. Circadian clock molecules CLOCK and CRYs modulate fibrinolytic activity by regulating the PAI-1 gene expression. J. Thromb. Haemost. 2006, 4, $2478-2485$. [CrossRef]

66. Merikanto, I.; Lahti, T.; Puolijoki, H.; Vanhala, M.; Peltonen, M.; Laatikainen, T.; Vartiainen, E.; Salomaa, V.; Kronholm, E.; Partonen, T. Associations of Chronotype and Sleep with Cardiovascular Diseases and Type 2 Diabetes. Chronobiol. Int. 2013, 30, 470-477. [CrossRef]

67. Makarem, N.; Paul, J.; Giardina, E.-G.V.; Liao, M.; Aggarwal, B. Evening chronotype is associated with poor cardiovascular health and adverse health behaviors in a diverse population of women. Chronobiol. Int. 2020, 37, 673-685. [CrossRef] [PubMed]

68. Roenneberg, T.; Allebrandt, K.V.; Merrow, M.; Vetter, C. Social jetlag and obesity. Curr. Biol. 2012, 22, 939-943. [CrossRef] [PubMed]

69. Spiegel, K.; Tasali, E.; Leproult, R.; Van Cauter, E. Effects of poor and short sleep on glucose metabolism and obesity risk. Nat. Rev. Endocrinol. 2009, 5, 253-261. [CrossRef] [PubMed]

70. Gangwisch, J.E. Epidemiological evidence for the links between sleep, circadian rhythms and metabolism. Obes. Rev. 2009, 10, 37-45. [CrossRef]

71. Maukonen, M.; Kanerva, N.; Partonen, T.; Kronholm, E.; Tapanainen, H.; Kontto, J.; Männistö, S. Chronotype differences in timing of energy and macronutrient intakes: A population-based study in adults. Obesity 2017, 25, 608-615. [CrossRef]

72. Kreier, F.; Yilmaz, A.; Kalsbeek, A.; Romijn, J.A.; Sauerwein, H.P.; Fliers, E.; Buijs, R.M. Hypothesis: Shifting the Equilibrium from Activity to Food Leads to Autonomic Unbalance and the Metabolic Syndrome. Diabetes 2003, 52, 2652-2656. [CrossRef]

73. Meier, A.H.; Cincotta, A.H. Circadian rhythms regulate the expression of the thrifty genotype/phenotype. Diabetes Rev. 1996, 4, 464-487.

74. Doherty, R.; Madigan, S.; Warrington, G.; Ellis, J. Sleep and nutrition interactions: Implications for athletes. Nutrients 2019, 11, 822. [CrossRef]

75. Greco, J.A.; Oosterman, J.E.; Belsham, D.D. Differential effects of omega-3 fatty acid docosahexaenoic acid and palmitate on the circadian transcriptional profile of clock genes in immortalized hypothalamic neurons. Am. J. Physiol. Regul. Integr. Comp. Physiol. 2014, 307, R1049-R1060. [CrossRef]

76. Ailhaud, G.; Massiera, F.; Weill, P.; Legrand, P.; Alessandri, J.; Guesnet, P. Temporal changes in dietary fats: Role of $\mathrm{n}-6$ polyunsaturated fatty acids in excessive adipose tissue development and relationship to obesity. Prog. Lipid Res. 2006, 45, $203-236$. [CrossRef]

77. IBGE. Brazilian Institute of Geography and Statistics. Family Budget Research-POF 2017-2018. Available online: https: / / biblioteca.ibge.gov.br/visualizacao/livros/liv101742.pdf (accessed on 12 March 2021). 
78. Muhlhausler, B.S.; Ailhaud, G.P. Omega-6 polyunsaturated fatty acids and the early origins of obesity. Curr. Opin. Endocrinol. Diabetes Obes. 2013, 20, 56-61. [CrossRef]

79. Scheer, F.A.J.L.; Hilton, M.F.; Mantzoros, C.S.; Shea, S.A. Adverse metabolic and cardiovascular consequences of circadian misalignment. Proc. Natl. Acad. Sci. USA 2009, 106, 4453-4458. [CrossRef]

80. Kolbe, I.; Oster, H. Chronodisruption, metabolic homeostasis, and the regulation of inflammation in adipose tissues. Yale J. Biol. Med. 2019, 92, 317-325. [PubMed]

81. Arango Duque, G.; Descoteaux, A. Macrophage Cytokines: Involvement in Immunity and Infectious Diseases. Front. Immunol. 2014, 5, 491. [CrossRef] [PubMed]

82. Leproult, R.; Holmbäck, U.; Van Cauter, E. Circadian misalignment augments markers of insulin resistance and inflammation independently of sleep loss. Diabetes 2014, 63, 1860-1869. [CrossRef] [PubMed]

83. Peuhkuri, K.; Sihvola, N.; Korpela, R. Diet promotes sleep duration and quality. Nutr. Res. 2012, 32, 309-319. [CrossRef] [PubMed]

84. Sato-Mito, N.; Sasaki, S.; Murakami, K.; Okubo, H.; Takahashi, Y.; Shibata, S.; Yamada, K.; Sato, K. The midpoint of sleep is associated with dietary intake and dietary behavior among young Japanese women. Sleep Med. 2011, 12, 289-294. [CrossRef] [PubMed]

85. Froy, O. The relationship between nutrition and circadian rhythms in mammals. Front. Neuroendocrinol. 2007, 28, 61-71. [CrossRef] [PubMed]

86. Imaki, M.; Hatanaka, Y.; Ogawa, Y.; Yoshida, Y.; Tanada, S. An Epidemiological Study on Relationship between the Hours of Sleep and Life Style Factors in Japanese Factory Workers. J. Physiol. Anthropol. Appl. Human Sci. 2002, 21, 115-120. [CrossRef]

87. Toktaş, N.; Erman, K.A.; Mert, Z. Nutritional Habits According to Human Chronotype and Nutritional Status of Morningness and Eveningness. J. Educ. Train. Stud. 2018, 6, 61. [CrossRef]

88. Sato-Mito, N.; Shibata, S.; Sasaki, S.; Sato, K. Dietary intake is associated with human chronotype as assessed by both morningnesseveningness score and preferred midpoint of sleep in young Japanese women. Int. J. Food Sci. Nutr. 2011, 62, 525-532. [CrossRef] [PubMed]

89. Kanerva, N.; Kronholm, E.; Partonen, T.; Ovaskainen, M.L.; Kaartinen, N.E.; Konttinen, H.; Broms, U.; Männistö, S. Tendency toward eveningness is associated with unhealthy dietary habits. Chronobiol. Int. 2012, 29, 920-927. [CrossRef] [PubMed]

90. Brasil. Health Ministry. Primary Care Information and Management System (e-Gestor). Available online: https://egestorab. saude.gov.br/paginas/acessoPublico/relatorios/relatoriosPublicos.xhtml (accessed on 12 March 2021).

91. Alves, C.G.; de Morais Neto, O.L. Trends in premature mortality due to chronic non-communicable diseases in Brazilian federal units. Cienc. Saude Colet. 2015, 20, 641-654. [CrossRef] [PubMed]

92. Jakubowicz, D.; Barnea, M.; Wainstein, J.; Froy, O. High Caloric intake at breakfast vs. dinner differentially influences weight loss of overweight and obese women. Obesity 2013, 21, 2504-2512. [CrossRef]

93. Brasil. Health Ministry. NASF Guidelines: Family Health Support Center. Available online: http://bvsms.saude.gov.br/bvs/ publicacoes/diretrizes_do_nasf_nucleo.pdf (accessed on 12 March 2021). 